Original Research Article

\title{
Comparison of different brands of centrally acting skeletal muscle relaxants: a cost analysis study
}

\author{
Kiran B., Kala P.*, Chitra N. S., Jamuna Rani R.*
}

Department of Pharmacology, SRM Medical College and Research Centre,

Kattankulathur,

Kancheepuram, Tamil Nadu, India

Received: 15 April 2019

Accepted: 13 May 2019

\section{*Correspondence to: \\ Dr. Kala P., \\ Email: kalaramesh75@ \\ gmail.com}

Copyright: (C) the author(s), publisher and licensee Medip Academy. This is an openaccess article distributed under the terms of the Creative Commons Attribution NonCommercial License, which permits unrestricted noncommercial use, distribution, and reproduction in any medium, provided the original work is properly cited.

\begin{abstract}
Background: Skeletal muscle relaxants are structurally distinct drugs prescribed for reducing muscle spasms, pain, and hyperreflexia. Centrally acting skeletal muscle relaxants are manufactured by various pharmaceutical companies with variable price. The present study, aimed to analyze the cost variation of various brands of centrally acting skeletal muscle relaxants, so as to help the physician to choose the cost effective treatment.

Methods: Current index of medical stores (CIMS) April 2018 and online literature were used as information guide to review the prices of drugs used in the treatment of musculo skeletal pain and spastic neurological disorders.

Results: Among anti spasmodic group, thiocolchicoside $4 \mathrm{mg}$ shows maximum price variation of $337.5 \%$, whereas carisoprodol $350 \mathrm{mg}$ shows the least variation of $0.1 \%$. It is evident from antispastic group that baclofen $10 \mathrm{mg}$ shows maximum price variation of $93.91 \%$ and $5 \mathrm{mg}$ of Baclofen shows the least variation of $11.22 \%$. It is observed that, among anti spastic group, a percentage prize variation of 93.91 for $10 \mathrm{mg}$ and 11.22 for $5 \mathrm{mg}$ baclofen. Largest \% prize variation is seen in metaxalone + diclofenac sodium $(400+50) \mathrm{mg}$ as $525 \%$ and the least variation is observed in tolperisone+ paracetamol $(150+325) \mathrm{mg}$ as $3.88 \%$.

Conclusions: Centrally acting orally effective skeletal muscle relaxants are commonly prescribed for painful musculoskeletal and spastic neurological disorders. Physicians should give due importance for the cost of the drugs while selecting appropriate drug for musculo skeletal disorders.
\end{abstract}

Keywords: Anti spasmolytic, Anti spasmodic, Cost analysis, Skeletal muscle relaxants

\section{INTRODUCTION}

Skeletal muscle relaxants are structurally distinct drugs prescribed for reducing muscle spasms, pain, and hyperreflexia. Neuromuscular blockers and spasmolytics are the two main groups of drugs referred as skeletal muscle relaxants. ${ }^{1}$

Neuromuscular blockers include depolarizing and non depolarizing blockers affecting Acetylcholine transmission in the neuro muscular junction which do not have CNS activity and are mainly given during surgery along with general anaesthetics to cause temporary muscle paralysis. ${ }^{2,3}$ Spasmolytics are usually referred as centrally acting muscle relaxants given by oral route, are of two types namely, anti spasmodic and anti spasticity agents. Antispasmodics are used to ease musculoskeletal pain associated with spasm such as low back ache, neck pain, fibromyalgia, tension headache and myofascial pain syndrome. Examples for antispasmodic drugs are carisoprodol, cyclobenzaprine, metaxalone, methocarbamol, orphenadrine and chloraxazone. ${ }^{4}$ Site of action of antispasticity agents are on the spinal cord to reduce the muscle tone due to upper motor neuron lesions in the spastic neurological conditions such as multiple sclerosis, cerebral palsy and spinal cord injuries. Baclofen, eperisone, tolperisone, thiocolchiocoside are the 
commonly used anti spastic agents. Drugs like diazepam and tizanidine are anti spasmodic - anti spastic agents. ${ }^{4}$ Spasmolytics are combined with NSAIDs for the treatment of musculoskeletal pain, which is a very common complaint presented to physician. Centrally acting skeletal muscle relaxants are manufactured by various pharmaceutical companies with variable price. The present study, aimed to analyze the cost variation of various brands of centrally acting skeletal muscle relaxants, to help the physician to choose the cost effective treatment for musculoskeletal pain.

\section{METHODS}

Current index of medical stores (CIMS) April 2018 and online literature were used as information guide to review the prices of orally active skeletal muscle relaxant drugs used in the treatment of musculo skeletal pain and spastic neurological disorders.

\section{Inclusion criteria}

- Orally active skeletal muscle relaxants

- Monotherapy and combinational drugs.

\section{Exclusion criteria}

- Parenteral preparations

- Topical preparations.

\section{Methods}

- The maximum retail price of a particular drug which was being manufactured by various pharmaceutical companies in the same dose, strength and number were compared
- Cost of skeletal muscle relaxant drugs were calculated as the number of tablets available per strip

- Maximum and minimum drug cost for the same formulation manufactured by different pharmaceutical companies were noted. The variation between the two drugs were considered.

\section{Statistical analysis}

Percentage cost variation was calculated as follows:

$\%$ Cost variation $=$ Maximum cost-Minimum cost $\times 100$

Minimum cost

\section{RESULTS}

The cost of 18 drugs (11 as monotherapy and 28 as fixed dose combinations) were analyzed. They are available in the market as oral tablets or capsules which are manufactured by different pharmaceutical companies.

\section{Monotherapy}

The prize variation of some commonly used centrally acting skeletal muscle relaxant drugs such as anti spasmodic, anti spastic drugs and anti spasmodic - anti spastic drugs prescribed as monotherapy are shown in Tables 1-3.

Table 1 shows among anti spasmodic group, Tablet thiocolchicoside $4 \mathrm{mg}$ shows maximum price variation of $337.5 \%$, whereas carisoprodol $350 \mathrm{mg}$ shows the least variation of $0.1 \%$.

Table 1: Cost variation of antispasmodic drugs.

\begin{tabular}{|lllllll|}
\hline Combination & Dose & Formulation & $\begin{array}{l}\text { Number of } \\
\text { manufacturing } \\
\text { pharma companies }\end{array}$ & $\begin{array}{l}\text { Minimum } \\
\text { cost (INR) }\end{array}$ & $\begin{array}{l}\text { Maximum } \\
\text { cost (INR) }\end{array}$ & $\begin{array}{l}\text { \% price } \\
\text { variation }\end{array}$ \\
\hline Carisoprodol & $350 \mathrm{mg}$ & 1 & 3 & 2.9 & 3 & 0.1 \\
\hline Chlorzoxazone & $500 \mathrm{mg}$ & 1 & 5 & 8.96 & 12.8 & 42.86 \\
\hline \multirow{3}{*}{ Cyclobenzaprine } & $5 \mathrm{mg}$ & 1 & 3 & 5.5 & 6.4 & 16.36 \\
\cline { 2 - 8 } & $15 \mathrm{mg}$ & 1 & 3 & 11 & 15.3 & 39.09 \\
\hline Metaxalone & $30 \mathrm{mg}$ & 1 & 2 & 21 & 24.16 & 15.05 \\
\hline Methocarbamol & $400 \mathrm{mg}$ & 1 & 2 & 7.8 & 11.7 & 50 \\
\hline \multirow{2}{*}{ Thiocolchicoside } & $500 \mathrm{mg}$ & 1 & 2 & 1.68 & 7.3 & 24.71 \\
\hline Eperisone & $4 \mathrm{mg} \mathrm{cap}$ & 1 & 7 & 1.67 & 2.98 & 337.5 \\
\hline \multirow{3}{*}{ Tolperisone } & $8 \mathrm{mg} \mathrm{cap}$ & 1 & 6 & 4.193 & 10.0 & 78.44 \\
\hline & $50 \mathrm{mg}$ & 1 & 3 & 5.5 & 9.193 & 92.57 \\
\hline
\end{tabular}


Table 2: Cost variation of antispastic drugs.

\begin{tabular}{|lllllll|}
\hline Combination & Dose & Formulation & $\begin{array}{l}\text { Number of } \\
\text { manufacturing } \\
\text { pharma companies }\end{array}$ & $\begin{array}{l}\text { Minimum } \\
\text { cost (INR) }\end{array}$ & $\begin{array}{l}\text { Maximum } \\
\text { cost (INR) }\end{array}$ & $\begin{array}{l}\text { \% Price } \\
\text { variation }\end{array}$ \\
\hline \multirow{3}{*}{ Baclofen } & $5 \mathrm{mg}$ & & 7 & 4.9 & 5.45 & 11.22 \\
\cline { 2 - 5 } & $10 \mathrm{mg}$ & 5 & 8.2 & 15.9 & 93.91 \\
\hline
\end{tabular}

Table 3: Cost variation of antispasmodic-antispastic drugs.

\begin{tabular}{|lllllll|}
\hline Combination & Dose & Formulation & $\begin{array}{l}\text { Number of } \\
\text { manufacturing } \\
\text { pharma companies }\end{array}$ & $\begin{array}{l}\text { Minimum } \\
\text { cost (INR) }\end{array}$ & $\begin{array}{l}\text { Maximum } \\
\text { cost (INR) }\end{array}$ & $\begin{array}{l}\text { \% Price } \\
\text { variation }\end{array}$ \\
\hline \multirow{3}{*}{ Diazepam } & $2 \mathrm{mg}$ & 1 & 3 & 0.66 & 1.2 & 81.82 \\
& $2.5 \mathrm{mg}$ & 1 & 2 & 8 & 9 & 12.5 \\
\cline { 2 - 7 } & $5 \mathrm{mg}$ & 1 & 12 & 0.35 & 11 & 3042.85 \\
\hline Tizanidine & $10 \mathrm{mg}$ & 1 & 6 & 1.5 & 2.4 & 60 \\
\hline
\end{tabular}

It is very evident from Table 2, that among antispastic group, Tablet baclofen $10 \mathrm{mg}$ shows maximum price variation of $93.91 \%$ and $5 \mathrm{mg}$ of baclofen shows the least variation of $11.22 \%$.

From Table 3, it is obvious that among anti spasmodic anti spastic group, a percentage prize variation of 93.91 for $10 \mathrm{mg}$ and 11.22 for $5 \mathrm{mg}$ baclofen.

\section{Fixed dose combination}

Table 4 shows, the variation in prize of centrally acting muscle relaxants such as anti spasmodic, anti spastic and anti spasmodic- anti spastic drugs in combination with NSAIDs. Largest \% prize variation is seen in metaxalone + diclofenac sodium $(400+50) \mathrm{mg}$ as $525 \%$ and the least variation is observed in tolperisone+ paracetamol $(150+325) \mathrm{mg}$ as $3.88 \%$.

\section{DISCUSSION}

In United States, low back pain is the most common complaint ranked among the top five most common reasons to visit the physician office. ${ }^{5-7}$ For low back pain, Acetaminophen or nonsteroidal anti-inflammatory drugs (NSAIDs) are the first line drugs as recommended by the American Pain Society and the American College of Physicians published guidelines in 2007. Skeletal muscle relaxants, benzodiazepines, and opioids may be prescribed for pain relief if the first-line agents are found to be ineffective. The selection of skeletal muscle relaxant is done depending upon duration and severity of symptoms, prior response to medications, side effects, and cost. ${ }^{8,9}$ Carisoprodol, cyclobenzaprine, and metaxalone were precribed for more than $45 \%$ for musculoskeletal pain as per Intercontinental Marketing Statistics (IMS) Health data from 2003-2004. ${ }^{10}$

The present study has observed, a large disparity in the prices of different brands of centrally acting orally effective skeletal muscle relaxant drugs available in the Indian market. The highest cost ratio and percent cost variation was found for diazepam $5 \mathrm{mg}$, followed by thiocolchicoside $4 \mathrm{mg}$, baclofen $10 \mathrm{mg}$.

Orally effective centrally acting skeletal muscle relaxants with maximum number of brands are diazepam $5 \mathrm{mg}$ followed by tolperisone $450 \mathrm{mg} .{ }^{11,12}$ One of the reason for non adherence to the treatment is the higher cost of the drug which leads to poor health outcome. ${ }^{11}$ Poor patient compliance leads to disease progression and indirectly increases the medical care expenses. Pharmaceutical industries have different strategies to market their pharmaceutical products.

Each drug is manufactured by different companies and there is wide variation in the prices of drug having the same concentration of chemical entity. There is no correlation found between the quality of the medicine and its corresponding price. ${ }^{12}$ It is crucial to regulate the pricing of different brands of the drug by concerned agencies.

Among doctors, there is a lack of awareness about price variation of drugs. In the developing country like India, inexpensive generic drugs should be prescribed by the doctor to reduce the cost to the patient which subsequently improves the patient compliance to the medication. Pharmacoeconomics should be included as an essential part of medical curriculum. This helps the medical students to concentrate on the cost effective treatment which in turn favor the successful treatment outcome. 
Table 4: Cost variation of fixed dose combination of antispasmodic, antispastic and NSAID drugs.

\begin{tabular}{|c|c|c|c|c|c|c|}
\hline Combination & Dose & Formulation & $\begin{array}{l}\text { No. of } \\
\text { manufacturing } \\
\text { pharma companies }\end{array}$ & $\begin{array}{l}\text { Minimum } \\
\text { cost (INR) }\end{array}$ & $\begin{array}{l}\text { Maximum } \\
\text { cost (INR) }\end{array}$ & $\begin{array}{l}\% \text { price } \\
\text { variation }\end{array}$ \\
\hline Aceclofenac & $100 \mathrm{mg}$ & \multirow{3}{*}{1} & \multirow{3}{*}{ ( } & \multirow{3}{*}{3} & \multirow{3}{*}{7.2} & \multirow{3}{*}{140} \\
\hline Chlorzoxazone & $250 \mathrm{mg}$ & & & & & \\
\hline Paracetamol & $325 \mathrm{mg}$ & & & & & \\
\hline Diclofenac & $50 \mathrm{mg}$ & \multirow{3}{*}{1} & \multirow{3}{*}{8} & \multirow{3}{*}{3} & \multirow{3}{*}{17.9} & \multirow{3}{*}{496.66} \\
\hline Chlorzoxazone & $500 \mathrm{mg}$ & & & & & \\
\hline Paracetamol & $325 \mathrm{mg}$ & & & & & \\
\hline Diclofenac & $100 \mathrm{mg}$ & \multirow{3}{*}{1} & \multirow{3}{*}{18} & \multirow{3}{*}{3} & \multirow{3}{*}{6.5} & \multirow{3}{*}{116.66} \\
\hline Chlorzoxazone & $250 \mathrm{mg}$ & & & & & \\
\hline Paracetamol & $325 \mathrm{mg}$ & & & & & \\
\hline Thiocolchicoside & $4 \mathrm{mg}$ & \multirow[b]{2}{*}{1} & \multirow{2}{*}{15} & \multirow{2}{*}{10.5} & \multirow{2}{*}{17.5} & \multirow{2}{*}{66.66} \\
\hline Aceclofenac & $100 \mathrm{mg}$ & & & & & \\
\hline Thiocolchicoside & $8 \mathrm{mg}$ & \multirow[b]{2}{*}{1} & \multirow{2}{*}{7} & \multirow{2}{*}{6.0} & \multirow{2}{*}{27.9} & \multirow{2}{*}{365} \\
\hline Aceclofenac & $100 \mathrm{mg}$ & & & & & \\
\hline Thiocolchicoside & $4 \mathrm{mg}$ & \multirow{3}{*}{1} & & & & \\
\hline Aceclofenac & $100 \mathrm{mg}$ & & 14 & 11.5 & 19.4 & 68.69 \\
\hline Paracetamol & $325 \mathrm{mg}$ & & & & & \\
\hline Thiocolchicoside & $4 \mathrm{mg}$ & 1 & & & & \\
\hline Etoricoxib & $60 \mathrm{mg}$ & 1 & 13 & 4.5 & 22.9 & 408.88 \\
\hline Thiocolchicoside & $8 \mathrm{mg}$ & 1 & 3 & & 23.9 & 13.81 \\
\hline Etoricoxib & $60 \mathrm{mg}$ & 1 & 3 & 21.0 & 25.9 & 15.81 \\
\hline Thiocolchicoside & $4 \mathrm{mg}$ & 1 & 6 & 12.5 & 27.0 & 116 \\
\hline Diclofenac & $50 \mathrm{mg}$ & 1 & 0 & 12.5 & 21.0 & 110 \\
\hline Thiocolchicoside & $8 \mathrm{mg}$ & 1 & 3 & 21.0 & 27.0 & 28.57 \\
\hline Diclofenac & $50 \mathrm{mg}$ & 1 & 3 & 21.0 & 21.0 & 20.51 \\
\hline Tizanidine & $2 \mathrm{mg}$ & 1 & 2 & 6.5 & 7.9 & 21.53 \\
\hline Aceclofenac & $100 \mathrm{mg}$ & 1 & 2 & $0 . J$ & 1.9 & 21.03 \\
\hline Tizanidine & $2 \mathrm{mg}$ & & & & & \\
\hline Aceclofenac & $100 \mathrm{mg}$ & 1 & 2 & 5.9 & 7.9 & 33.89 \\
\hline Paracetamol & $325 \mathrm{mg}$ & & & & & \\
\hline Tizanidine & $2 \mathrm{mg}$ & 1 & 4 & 3.2 & 43 & 34.375 \\
\hline Mephenamic acid & $500 \mathrm{mg}$ & 1 & $T$ & 3.2 & $T . J$ & (נ) \\
\hline Tizanidine & $2 \mathrm{mg}$ & 1 & 11 & 3.5 & 8.25 & 135.71 \\
\hline Ibuprofen & $400 \mathrm{mg}$ & 1 & 11 & J. & & \\
\hline Tolperisone & $150 \mathrm{mg}$ & 1 & 2 & 9.9 & 10.285 & 3.88 \\
\hline Paracetamol & $325 \mathrm{mg}$ & 2 & & & & \\
\hline Tolperisone & $150 \mathrm{mg}$ & 1 & 2 & 13.01 & 14.28 & 9.76 \\
\hline Diclofenac & $50 \mathrm{mg}$ & 1 & 2 & 15.01 & 14.20 & 9.10 \\
\hline Metaxalone & $400 \mathrm{mg}$ & 1 & 7 & 8.0 & 50 & 525 \\
\hline Diclofenac potassium & $50 \mathrm{mg}$ & 1 & 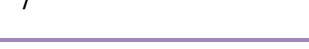 & 0.0 & 50 & 年 \\
\hline
\end{tabular}

\section{CONCLUSION}

Centrally acting orally effective skeletal muscle relaxants are commonly prescribed for painful musculoskeletal and spastic neurological disorders. These drugs are usually given as fixed dose combination with non steroidal anti inflammatory drugs. Physicians should give due importance for the cost of the drugs along with careful consideration of individual variables in a given clinical situation while selecting appropriate drug for musculo skeletal disorders.

Funding: No funding sources

Conflict of interest: None declared

Ethical approval: Not required

\section{REFERENCES}

1. Van Tulder MW, Touray T, Furlan AD, et al. Muscle relaxants for nonspecific low back pain: A systematic 
review within the framework of the Cochrane Collaboration. Spine. 2003;28:1978-92.

2. Definition of Muscle relaxant. Available at: MedicineNet.com. (c) 1996-2007. (Accessed on 21 May 2019).

3. Muscle relaxant. Available at: mediLexicon. (c) 2007. (Accessed 20 May 2019).

4. Witenko C, Moorman-Li R, Motycka C, Duane K, Hincapie-Castillo J, Leonard P, et al. Considerations for the appropriate use of skeletal muscle relaxants for the management of acute low back pain. Pharma Therapeutics. 2014;39(6):427.

5. Chou R, Qaseem A, Snow V, Casey D, Cross JT, Shekelle P, Owens DK. Diagnosis and treatment of low back pain: a joint clinical practice guideline from the American College of Physicians and the American Pain Society. Ann Internal Med. 2007;147(7):478-91.

6. See S, Ginzburg R. Skeletal muscle relaxants. Pharmacotherapy. 2008;28(2):207-13.

7. See S, Ginzburg R. Choosing a skeletal muscle relaxant. Am Fam Physician. 2008;78(3):365-70.

8. Atlas SJ, Deyo RA. Evaluating and managing acute low back pain in the acute care setting. J Gen Intern Med. 2001;16(2):120-31.
9. Van Tulder MW, Touray T, Furlan AD, Solway S, Bouter LM. Muscle relaxants for nonspecific low back pain: a systematic review within the framework of the cochrane collaboration. Spine. 2003;28(17):1978-92.

10. Toth PP, Urtis J. Commonly used muscle relaxant therapies for acute low back pain: a review of carisoprodol, cyclobenzaprine hydrochloride, and metaxolone. Clin Ther. 2004;26(9):1355-67.

11. Garnett WR. Antiepileptic drug treatment: outcomes and adherence. Pharmacotherapy: J Hum Pharmacol Drug Therapy. 2000;20(8P2):191S-9S.

12. Gagne JJ, Kesselheim AS, Choudhry NK, Polinski JM, Hutchins D, Matlin OS, et al. Comparative effectiveness of generic versus brand-name antiepileptic medications. Epilepsy Behav. 2015;52:14-8.

Cite this article as: Kiran B, Kala P, Chitra NS, Rani JR. Comparison of different brands of centrally acting skeletal muscle relaxants: a cost analysis study. Int J Basic Clin Pharmacol 2019;8:1419-23. 